\title{
原子力技術基盤の維持・強化・伝承に対する 原子力総合メーカとしての取り組み*
}

\author{
内田誠*1, 桶谷浩一郎*2

\section{Activities to Maintain, Strengthen and Hand Down the Nuclear Technology Base} \\ Makoto UCHIDA and Koichiro OKETANI*3 \\ ${ }^{* 3}$ Mitsubishi Heavy Industries Ltd. Nuclear Systems Engineering Department, \\ 2-16-5 Konan, Minato-Ku, Tokyo, 108-8215 Japan

\begin{abstract}
The recent worldwide "Nuclear Renaissance" is encouraging the globalization of our nuclear business and making us aware of the increasing importance of the human education and trainings for it. The basic concept of MHI's human resource development and its improvement is "The improvement in the skills and motivation of each employee leads to the strengthening of the company wide technology base". Under this concept we are improving our job efficiency continuously by means of information technology, institutionalizing the means to improve the individual skills and motivation and investing for the effective succession of the skills. In order to take real advantage of those efforts for maintaining, strengthening and effectively handing down the nuclear technology base, it is imperative to keep the volume of actual jobs. So, we have to keep in mind that having actual business continuously is extremely important to keep the sound and solid technology base.
\end{abstract}

Key Words: Nuclear Engineering, Educational Equipment, Engineering Education, Nuclear Technology Base

\section{1. はじめに}

近年の原子力ルネッサンスの気運の高まりと共に 積極的な海外展開を図っていく中で, 産業界における 人材育成の重要性が益々高くなっている.

原子カプラントメーカの使命を果たすためには，原 子力技術基盤の維持・強化・伝承が必要で，その担い 手となる人材の育成は重要な課題であり，また団塊の 世代の大量退職や学生の原子力離れなどの厳しい環境 下に㧍ける人材確保も重要な課題と認識している.

本稿では三菱重工の原子力部門で実施されている 技術基盤の維持・強化・伝承手法について紹介する。

\section{2. 技術基盤強化活勳のコンセブト}

原子力プラントを支えている技術分野は図 1 に示す ように研究開発, プロジェクトマネジメント，基本計 画, 基本設計, 詳細設計, 製作/検查，据付／試軍転， 保全と多岐に渡り，その全分野で技術基盤の維持・強 化・伝承が行われている，その活動コンセプトは「個 人の技術レベルの向上を組織的な技術基盤強化に展開 する」というものであり，具体的には以下に示す方策

* 原稿受付 2008 年 9 月 22 日.

*1 三菱重工業(株) (事 108-8215 東京都港区港南 2-16-5).

*2 正員, 三菱重工業 (株) ( $652-8585$ 神戸市兵庫区和田崎町 1-1-1).

E-mail : koichiro_oketani@mhi.co.jp
等が行われている.

（1）IT を活用した業務による技術力向上

（2）技術者の技術力強化のための制度運用

（3）技術伝承のための設備投資 等

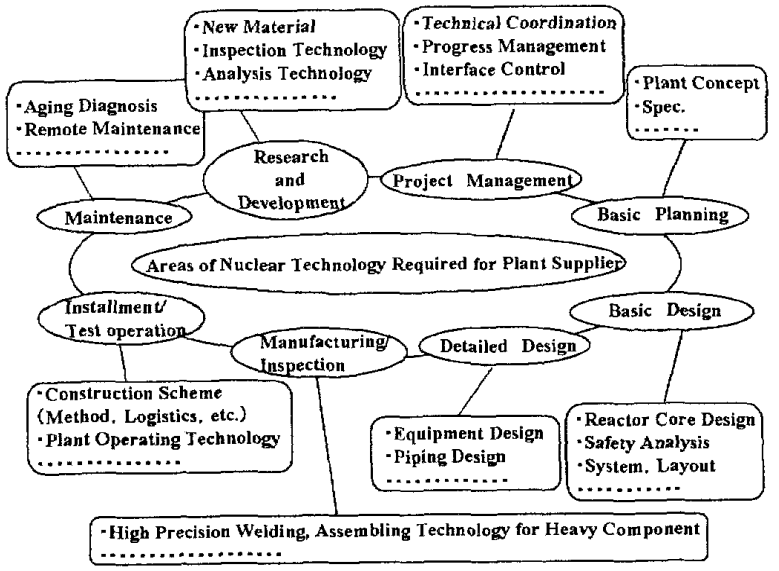

Fig.1 Areas of nuclear engineering technology in plant maker

以下，設計，製作，据付・保守の分野での活動の一 端を，人材育成等の例を示しつつご紹介する.

\section{3. 設計技術の向上}

設計技術関係では, 以下の示す方策などにより設計 者の技術カレベルの向上を行っている.

（1）OJT 業務の高度化による技術レベルの向上 
3D-CAD によるコンカレントエンジニアリングを 通じて上流から下流まで設計を同時に遂行している. 設計者は実務を通じて設計に必要な幅広い技術を効率 的に習得できる.

（2）原子力設計技術基盤強化制度の制定と運用

設計者は技術力向上の目標を管理者との面談で定 め, その目標を達成するために必要な技術能力を計画 的に修得する制度を運用している. 修得した技術能力 はデータベースに登録管理される．管理者はこのデー 夕を集計分析し組織軍営に必要な技術力を保有してい るかを評価し，その結果を各設計者の技術能力の習得 活動に展開する $\mathrm{PDCA}^{*}$ の仕組みを運用している.

（3）技術伝承手法としてのマニュアル化や DB 化

設計根拠などを明文化し暗黙知を形式知に変換し， ノウハウ伝達ツールの整備を行っている. IT 技術を援 用した暗黙知のビジュアル化である.

\section{4. 製造技術の向上}

製造技術関係では，以下に示す方策などにより人材 育成を行っている.

（1）集合教育（基礎技量の習得）

規律教育や溶接・組立・機械加工等, 要素技量訓練

（2）OJTによる専門技量訓練

配属先での専門業量訓練, 上位作業者との共同作業 による OJT

（3）製造技術資格認定制度の制定

社内訓練センターでの技量資格取得や技能オリン ピックなどの社外コンテスト参加

（4）エキスパートによる指導・教育

現場での, 作業者への問いかけ, 設計根拠の説明, 製品の「出来栄え」確認, 作業の「勘どころ」指導, ルール遵守状況確認 等を行い（図 2), 座学としても 「ものづくり勉強会」を開催してエキスパートから若 手や作業キ一マンにノウハウや失敗体験, 原子力工事 従事者としての心構えを伝達している.

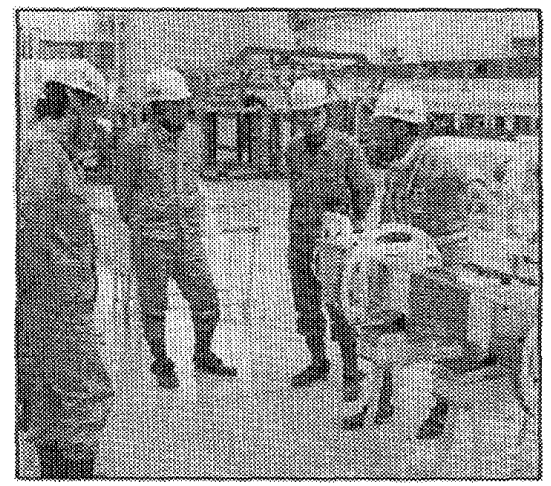

Fig.2 Teaching by expert in factory

*4 ‥Plan 計画, Do 実行, Check 評価, Action 改善

\section{5. 据付技術 · 保守技術の向上}

据付技術・保守技術関係では，メ一力ー独自の補修 訓練センターを設立し, 据付, 補修, 点検作業のトレ ーニングを行っている.

\section{6. モチベーションの向上}

人間の行動に大きく作用するモチベーションの向 上策としては，技監／範師制度や各種表彰制度等を導 入している.

・技監/範師制度の制定と運用

スペシャリストの最高峰である「技監」称号, 技能 の最高峰である「範師」称号の認定制度を制定し, 顕 彰を行っている.

-事業所表彰, 部内競技会表彰, 優良技術者表彰

業務上の優れた業績を表彰している.（図 3）

・社内報での製品紹介, 出荷時の記念撮影（図 3)

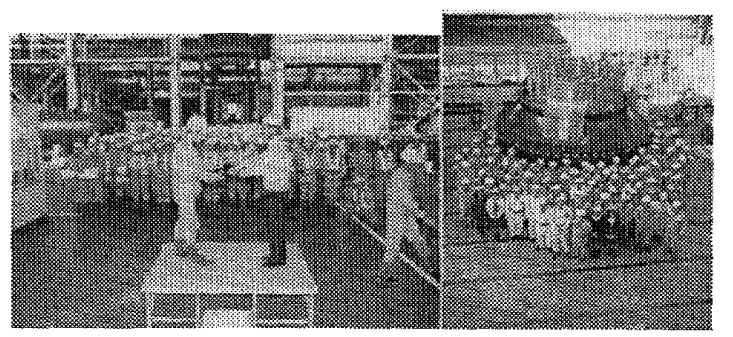

Fig3 Awarding ceremony, Ceremonial photo

\section{7. おわりに}

以上，三菱重工の原子力部門で実施されている技術 基盤向上策についてその一端をご紹介したが，これら の種々の取組みを積極的に進める一方で, 継続的に工 事を確保し，実際の作業体験の中で人材育成を図って いくことが不可欠であることは言うまでもない.

また，この小文の内容は，第 13 回動力・エネルギ 一技術シンポジウムでの講演を纒めたものであるが, 講演後に原子力従事者として求められる資質につきご 質問があり，それにお答えする形で，これから原子力 界に入ってこられる学生さんに求めるものをお話しし たので,ここでもご紹介しておきたい.

そこでは，まず「志」，つまり，原子力を通じて社 会貢献したいという気持ちを持っていることが大事で あるとお答えした．根幹にこのような気持ちを持って いればこそ原子力を信頼ある技術として育てていける 亡信じている. 次に「基礎的な学力」とお答えした. 勉強は学校だけでは終わらない. 社会人になってから 業務上勉強が必要になる場面が少なからずある。この 時必要なものとして「基礎的な学力」とお答えした次 第である.「志」ある若者の原子力産業界への参加を 期待するものである. 